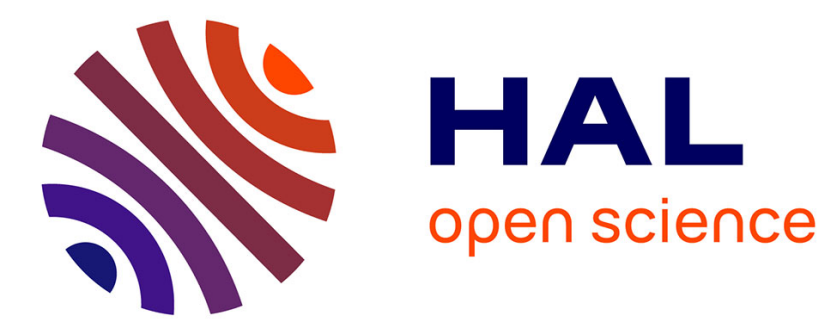

\title{
Lex alterius: Using Law to Construct Confessional Boundaries
}

John Tolan

\section{- To cite this version:}

John Tolan. Lex alterius: Using Law to Construct Confessional Boundaries. 2014. halshs-00998402

\section{HAL Id: halshs-00998402 \\ https://shs.hal.science/halshs-00998402}

Preprint submitted on 2 Jun 2014

HAL is a multi-disciplinary open access archive for the deposit and dissemination of scientific research documents, whether they are published or not. The documents may come from teaching and research institutions in France or abroad, or from public or private research centers.
L'archive ouverte pluridisciplinaire HAL, est destinée au dépôt et à la diffusion de documents scientifiques de niveau recherche, publiés ou non, émanant des établissements d'enseignement et de recherche français ou étrangers, des laboratoires publics ou privés. 


\title{
Lex alterius: Using Law to Construct Confessional Boundaries
}

John TOLAN

\begin{abstract}
Historiens et anthropologues doivent faire face à un problème méthodologique de taille, sans solution évidente : les outils conceptuels que nous employons pour essayer de comprendre des faits sociaux et culturels sont eux-mêmes les produits, souvent, des sociétés que nous tentons d'analyser. C'est le cas, par exemple de la religion. Daniel Boyarin (2004) affirme que le concept même de "religion » est un produit des IVe et Ve siècles, lors qu'évêques et empereurs érigèrent le christianisme en "religion » (la vraie religion pour eux, bien entendu) et construisirent le " judaïsme » et «l'hellénisme» (ce que nous appelons le paganisme) comme «fausses » religions. Pour Boyarin, le judaïsme ne devient religion qu'à partir du moment que les autorités chrétiennes impériales le définissent en tant que telle. On pourrait dire de même pour l'agglomérat de textes, croyances et rituels que les Britanniques, en arrivant en Inde, rassemblèrent sur l'appellation de "l'hindouisme ", qu'ils définirent comme une religion. Bâtir, définir et policer des frontières entre groups confessionnels a été (et l'est toujours) un moyen important pour construire des identités, ou "visions de communautés » en maintes sociétés, surtout celles dont les dirigeants s'associent au christianisme ou à l'islam, et ce depuis les règnes des premiers empereurs romains chrétiens. Que fallait-il faire ou croire pour être considéré membre de la communauté confessionnelle dirigeante? Quelles étaient les doctrines, affiliations institutionnelles, ou performances rituelles dont il fallait faire montre? Comment définissaient d'autres groups religieux? Quelle en était leur légitimité sociale? Que faire de ceux qui ne semblaient appartenir à aucun groupe reconnu légitime, qu'on définissait comme hérétiques ou syncrétistes? Dans cet article, j'étudie les manières dont les juristes chrétiens et musulmans du IVe au XIe siècles employèrent la loi pour définir et policer les frontières entre groups confessionnels, en particulier comment ils tentèrent de limiter les interactions qui risquaient de transgresser ces frontières : la commensalité, la sexualité interconfessionnelle et les pratiques syncrétiques.
\end{abstract}

Historians and anthropologists are confronted with a persistent problem for which there is no clear solution: the conceptual tools which we use to attempt to understand cultures are themselves products of (often) the very cultures we are attempting to understand. Take "religion". Daniel Boyarin (2004) has argued that the very concept of "religion" as we know it was a product of the fourth and fifth centuries, as bishops and emperors constructed Christianity as a religion (the true one, of course), and in counterdistinction constructed "Judaism" and "Hellenism" (or paganism) as "false" religions. For Boyarin, Judaism only becomes a "religion" when Christian authorities define it as one. The same could be said for the jumble of texts, beliefs and rituals that the English, upon arriving in India, lump together under the name "Hinduism", which they turn into a religion. Building, defining and policing borders between confessional groups has been an important part of constructing identities - or visions of community-in various societies, in particular those ruled by Christians or Muslims, from the time of the fourth-century Christian Roman emperors. What did one have to do to be considered belonging to the "true" or dominant religious community: what doctrines, institutional affiliations, or ritual performances were necessary? How were other religions defined as separate and legitimate? What to do with those who seemed to fit in no category of accepted religion: the realm of syncretists and heretics? In this article, I examine how Christian and Muslim jurists of the fourth to eleventh centuries use law to define and police confessional boundaries, in particular how they attempt to limit interactions that could transgress or blur those boundaries: shared meals, sexual contact, syncretic practices. 


\section{$* * *$ \\ Lex alterius: Using Law to Construct Confessional Boundaries ${ }^{1}$}

\section{John Tolan}

What is 'community'? The late 20th and early 21 st centuries have seen a salutary scepticism concerning the conceptual categories of the 19th century, whether they involve scientific (biological/genetic) attempts to divide humanity into 'races' or social-scientific categorizations into 'ethnicities' or 'tribes'. Such labels indeed need to be handled with caution, yet at times, in order to avoid their drawbacks, scholars substitute imprecise and unhelpful terms: 'group' and 'community' have both the merits and the pitfalls of their broadness and vagueness. As Andre Gingrich notes in these pages (concerning Yemen), 'substituting a very general, non-descriptive and formal term (community) for an indigenous term (qabila) and its partially problematic translation (tribe) is not a good solution, but is deeply problematic in itself.' The historian and the anthropologist are constantly confronted with the question of the appropriateness of their conceptual categories for understanding societies distant in space and time. Our own concepts (here, 'tribe') need to be defined (and their implications fleshed out) and compared with roughly equivalent terms in the society studied (here, qabila), always of course bearing in mind that these terms can have multiple meanings and may evolve over time. ${ }^{\mathrm{i}}$

In the following pages, I would like to look at the evolution of two key concepts, 'law' and 'religion', and in particular at how law is used to define, identify, structure and enforce boundaries between religious groups. My time frame is the 5th to 12 th centuries, a key formative period for the religious and legal systems of Christian and Islamic societies around the Mediterranean basin. I will in particular be looking at how law distinguishes between

\footnotetext{
${ }^{1}$ The research leading to this publication has received funding from the European Research Council under the European Union's Seventh Framework Progamme (FP7/2007-2013) /ERC grant agreement n²49416.
} 
groups which it identifies as Jews, Christians and Muslims. Here again, historians like anthropologists are confronted by problems of terminology: to what extent is it useful to use our own categories (law, religion) on societies distant (in time, space) from our own? The danger lies in assuming that these categories apply to recognizable phenomena that one finds in all cultures.

We will need to pay close attention to terms used by the sources and how those terms evolve over time. The appropriate languages for our period and geographical area are numerous, and could potentially include Syriac, Greek, Hebrew, Coptic etc. To keep things (relatively) simple, I am going to focus on terms in Latin and in Arabic. In the lexical field of law, we will have to look at the meanings of Latin terms such as ius and lex, and Arabic terms such as sharī' $a$ and fiqh. In addition we will be paying attention to terms used to describe texts concerning laws and their application and interpretation as well as terms designating those who practice law or implement or enforce law. For 'religion' we will be looking at Latin terms such as religio, superstitio, fides, cultus and the Arabic terms dīn and sharì' $a$. Over the eight centuries that concern us, moreover, the meanings of these terms evolve, in some cases changing radically depending on period, context and individual author. What's more, while 'religion' and 'law' are clearly separate categories in 21st-century English, in Medieval Latin and Arabic they overlapped in crucial ways.

I want to look at how these concepts shift and at how religious boundaries are defined and policed through legal texts during four watershed periods in legal history: 1 . The emergence of 'religion' as a key element of personal law in the Christian Roman Empire (4th-6th centuries); 2. Religious identity and judicial pluralism in Late Antiquity and the Early Middle Ages (5th-7th centuries); 3. The expansion of Islam and the creation of a protected and subordinate dhimmī status; 4. The 'rediscovery' of Roman law and the refoundation of canon law (11th-12th centuries). 


\section{The emergence of 'religion' as a key element of personal law in the Christian Roman Empire (4th-6th centuries)}

Ancient Latin has two principal terms that may be translated in English as 'law': lex and ius. Etymologically, it seems that both come from verbs that mean to bind or attach (jungere, ligere), suggesting the binding nature of law. But ius is much broader than lex. For Cicero, ius civile consists of lex, mos (custom) and equitas (fairness). ${ }^{\mathrm{ii}}$ In other words the lex, as written and transmitted by Roman authorities, was only one of the sources of ius. As Alain Supiot has pointed out, while English has one term, law, to render both Latin notions, most European languages have distinct terms for ius (droit, derecho, diritto, Recht) and for lex (loi, ley, legge, Gesetz). (Supiot, 2005: 27-29, 85-86; Magdelain, 1990, Schiavone, 2005: ch. 1 \& 4) A European jurist studies droit (or derecho, diritto, Recht), to which he then will devote his career; knowledge concerning the laws (lois, leyes etc.) enacted by various governments are only one aspect of his study. This apparent linguistic accident corresponds to a difference of legal culture and legal practice. Anglo-American law is based more on common law notions and on legal precedent (with an accusatory legal system based on opposing parties of accusation and defence with a neutral judge and jury). Continental law is based more on the traditions of Roman law enshrined in written codes (with an inquisitorial legal system in which the judge takes an active role in the investigation of the allegations). Hence we see that even within 20th or 21 st century European traditions, an Anglophone scholar may come up against unexpected cultural barriers when he tries to understand the place of 'law' in other cultures: these barriers are of course more imposing as one looks at cultures more distant in space and time, often raising the question of the legitimacy (or relevance) of the chosen categories. 
What about religion? The Latin term religio comes from the same root as lex: ligere, to bind. Service to the gods is also 'binding'. Religio refers both to an attitude of reverence, respect and fear of the gods and to the devotion shown towards them. The term is almost never used in the plural in classical Latin: religio is a general attitude and behaviour that can be adopted toward one or many gods. While each god/goddess has his/her own specific cult and rituals, in no sense do these amount to different 'religions'. Hence an ancient Roman would not understand the question 'what religion are you?'. (Bendlin, 1995) Religion in the ancient Mediterranean was often (though by no means always) associated with civic governance. Thus for an Athenian, the festivals associated with Athena were civic, political and religious events of major importance: these different elements were inextricable. For Romans, the same is true for the cult of Vesta or Capitoline Jupiter - and, later, for the cult of the deified emperors. Refusal to participate would indicate lack of civic duty as well as religious duty. Jews were early granted exemptions from taking part in traditional Roman cults, but these privileges were granted to Jews as a people or ethnos, not a 'religion'. The Romans had many accords with different nations (gentes or ethnoi), recognizing their rights to maintain traditional social, legal and at times cultic practices. Roman accords with the Jews were thus nothing exceptional, even if certain stipulations were unique to the Jews (not bringing imperial insignia into the city of Jerusalem, exempting Jews from participating in cults of Roman deities, not summoning them to court on the Sabbath, etc.). (Pucci Ben Zeev, 1995) The concept of religion as we know it is in many ways a product of the 4th and 5th century Christian Roman Empire. The Christian movement was born as a faction within Judaism and, starting principally at the time of Paul, proselytized among non-Jews, who eventually make up the majority of Christians. A diffuse, geographically dispersed, eclectic and disorganized movement, facing sporadic (and at times intense) persecution from Roman officials. In the 1st century, bishops emerged as the leaders of Christian communities of the Empire's cities, but their modes of election and scope of authority varied widely. Among those who identified 
themselves as Christians, there was no firmly established doctrine, and there were widely diverging attitudes concerning (among other things) Jewish cultic practices, the observance of Jewish holidays, frequenting of synagogues, Hellenic philosophy and the authority of the Roman state.

It is the edict of Milan of 313 and the favour shown to Christians by Constantine that permitted the development of the Church as an institution and the establishment of commonly-agreed doctrines. In 325, Constantine called the council of Nicaea, the First Ecumenical Council of the Church, which established the credo (or Nicene Creed): the basic statement of faith to which every Christian is supposed to adhere. It also established the primacy of four bishops, those of Jerusalem, Alexandria, Antioch and Rome (Constantinople would later be added to the list), who in theory exercised authority over lesser bishops. Arguably, Nicaea represents the invention of Christianity as the first 'religion' in the modern, commonly-accepted sense of the term: a 'faith' to which its members must adhere (the Creed) and a 'Church' structured along hierarchical lines. There was never a 'credo' defining what Jews had to believe, nor of course was there ever one for the adepts of Jupiter, Athena or Isis. And while many cults (including that of the Jews) had priestly castes closely allied to political power, the structure of the new Christian church was meant to be more far-reaching and universal. It was of course one thing for emperor and bishops to agree to a creed and to their own authority over the emerging Christian Church, quite another to impose this idea on Christians throughout the empire. Under Constantine the bishops emerged as new important players in the politics of the Empire, in many ways obtaining the privileges and influence formerly held by the senatorial class. (Drake, 2000)

If in the 4th century Christianity became the first 'religion', it was to inspire imitators. Julian the Apostate ruled the empire from 355 to 360 and sought to restore the traditional pagan practices of the Empire, authorizing sacrifices and other cultic practices that his predecessors had outlawed, restoring and reopening temples, or reconverting those that had been made into churches. Julian sought to 
revive the traditional cults, yet as Susanna Elm has shown, his conceptions were deeply coloured by the struggle with Christianity: Julian invented paganism (or 'Hellenism' as he called it) as a religion, endowing it with a creed and a coherency that traditional Roman cultic practices had never known. (Elm, 2012)

While Julian's restoration of 'Hellenism' as a state religion was short-lived, another 'religion' was to become defined over and against Christianity: Judaism. Daniel Boyarin speaks of a process of 'Christian invention of Judaism' in the 4th and 5th centuries, as Christian writers define orthodoxy over and against those outside that orthodoxy: Jews, 'Hellenes' and heretics. The Roman state plays a key role in the institutionalization of the Christian church, as we see notably through the Theodosian Code, promulgated in 438 by Theodosius II, which brings together laws of Christian emperors from Constantine I to Theodosius II. These laws characterize Judaism as a 'sect' (secta CTh 16.8.2, 8.8, 8.9), sometimes adding for good measure qualifiers such as 'beastly' or 'nefarious' (feralem sectam 16.8.1; nefariam sectam 16.8.1). At other times laws refer to Jewish 'perversity' or 'incredulity' (perversitatem iudaicam 16.8.19; incredulitate judaica 16.8.19). In other places the term 'superstition' is used (Iudaica superstitione 16.8.24; tenebris superstitionis 16.8.28). Here superstitio, like religio, has taken on a new meaning: superstitio is the opposite of religio, it is false religio. (Le Code Théodosien: Livre Xvi Livre Xvi, 2005; Boyarin, 2004)

Yet other laws present Judaism as a religio alongside Christianity. Various laws decree protection of synagogues, respect for the Sabbath (Jews may not be summoned to court on a Saturday), etc.. (Nemo-Pekelman, 2010) Moreover, a hierarchy of Jewish officials was recognized and given, quite explicitly, the same privileges as the high officials of the Christian church, creating what Amnon Linder has called a 'Jewish Church'. (Linder, 2006: 157) In other words, imperial officials and bishops recognized 'Judaism' as a religion at the same time that they sought to keep it distinct and separate from Christianity and the Christian Church. At the same time, a rabbinical elite that had succeeded in obtaining social and 
intellectual dominance within the Jewish community not only accepted these developments, but actively embraced them. In other words, emerging Jewish and Christian religious elites defined the new Jewish and Christian 'religions' and 'churches' and strove to erect a firm and watertight barrier between the two. (Boyarin, 2004)

It has often been posited that legal restrictions on Jews are driven by theological considerations. This is the classic thesis of Jean Juster, who saw in the anti-Jewish legislation of the Theodosian code the fruits of Church pressure on the Christian Roman Emperors. A socalled 'Augustinian doctrine' of Judaism relegated Jews to a protected but subordinated social and legal status. In various works, Augustine addresses the role of Jews in Christian society. (Signer, 1999; Fredriksen, 2008) In the City of God (XVIII:46), he explains that the Jews who put Jesus to death and failed to believe in him were in consequence crushed by the Romans and sent into exile among the nations. Since they are found everywhere, they serve as witnesses, 'living letters of the law': proof in the flesh both of the truth of the scriptures which they preserve in the original Hebrew and of the humiliation meted out by Christ to those of his people who refuse to recognize Him as their Lord. (Cohen, 1999) While Christian heretics (such as the Donatists) should be compelled to conform to the Catholic faith, Jews should be allowed to live in peace among Christians. They preserve in error the ancient covenant and through their error, and their subservient place in Christian society, serve as unwitting witnesses to the superior truth of Christianity. Moreover, the Jews will, of their own will, massively convert to Christianity at the end of time: this, indeed, will be one of the signs that the end is near. For Jean Juster, the 4th- and 5th-century emperors translated this theological vision into a legal programme, creating a protected and inferior legal and social status for Jews in a now Christian Roman Empire. Yet in fact, as Capucine Nemo-Pekelman has shown, these Christian emperors are in no way establishing a coherent, theologically centred Jewry law: rather their laws are more often than not reacting to specific situations at the request of various individuals — sometimes bishops or imperial officials, sometimes Jews. 
(Juster, 1914; Nemo-Pekelman, 2010) When the jurists working for Theodosius II codify these laws, they do indeed group most of them together in a chapter devoted primarily to Jews, showing an attempt to lay the groundwork for specific restrictions concerning Jews. If anything, it is the theologians, such as Augustine, who are responding to social and legal realities and not the other way around: confronted with Emperors who issued legal guarantees to Jews, they found theological justifications for a social status quo that they had not chosen, that explained why Christians allowed Jews to live in their midst.

At the same time as bishops and other men of the Church drew sharp distinctions between Christians and Jews, they attempted to affirm their authority over Christians and to brand deviant Christians as 'heretics'. The definition of orthodoxy and suppression of heresy thus became major preoccupations of bishops, Church councils and, to a certain extent, emperors. While historians of the Church, dependent on the narratives of Eusebius and his followers, stress the doctrinal nature of these disputes, Harold Drake and others have rightly emphasized the importance of personal and political dimensions of these disputes: as important as (or often more important than) what is defined as orthodoxy is who has the authority to define and enforce orthodoxy and what coercive measures are to be taken against those who do not recognize that authority. Constantine and his successors exile recalcitrant bishops; at times, more violent methods were employed — notably the use of imperial troops against Donatists in North Africa. (Drake, 2000)

Yet councils, patriarchs and emperors were never successful in imposing unity on the Church. On the contrary, a plurality of churches emerged alongside the Church officially recognized by the emperors: churches of Arians, Miaphysites (also known as Monophysites), and other dissenters from Chalcedonian orthodoxy. These churches had their own legal-institutional hierarchies (with their own bishops and priests) and eventually their own distinct liturgical languages (Armenian, Coptic, Syriac, etc.). 
To sum up, the Christian concept of 'religion' was born in the struggles with rival traditions. Christianity comprised the first 'church' and first 'religion' and subsequently both Christian and non-Christian authors defined Hellenism and Judaism as rival 'religions'. This background knowledge is essential not only for historians of ancient and medieval Judaism and Christianity, but for all those (historians, anthropologists, sociologists and others) who work on 'religion'. Since the 5th century, 'religion' implies a unified doctrine or credo and often a hieratically organized church with a professional clergy. Our everyday concept of religion is inextricably wound up with the history of Christianity, which explains why it is often an awkward or inappropriate tool for understanding other societies: witness the frequent scholarly debates on whether Buddhism, Confucianism, Judaism etc. are or are not 'religions'.

\section{Religious identity and judicial pluralism in Late Antiquity and the Early Middle Ages} (5th-7th centuries)

One of the pitfalls of much 19th- and 20th-century legal scholarship, as anthropologist Leopold Pospíšil noted in 1971, is to assume that any given society operates under one legal system, when in fact multiple systems of regulation and conflict resolution often coexist in the same society. (Pospisil, 1971: 99-106) Pospíšil attributes this common error to a Western prejudice based on Roman law, which claimed to emanate from a sole legitimate authority and to apply to the whole empire. But in fact the Roman Empire also knew considerable judicial pluralism. In theory, we can distinguish between legal pluralism (more than one law system having authority in the same territory) and multiple jurisdictions (more than one venue for judgement). ${ }^{\text {iii }}$ Legal pluralism was a constant in the Roman system, as Romans granted privileges to different gentes who incorporated the empire; such pluralism tended to diminish, at least in theory, with the widespread accordance of Roman citizenship. At the same time, in 
particular between the 4th and 7th centuries, jurisdictions multiply, as alternate venues for adjudication emerge and gain importance. In Christian Rome/Byzantium, access to the 'official' Roman justice system was costly and bureaucratic, and was usually an option in major criminal cases and in cases in which wealthy and powerful individuals felt they could benefit from the system. With reduced fees for the elite, and judges taken from the Roman elite, the system carried a clear social bias and many complained of corruption. Fees for getting a court hearing could be roughly the equivalent of costs of feeding someone for a year. So naturally plaintiffs sought alternate venues for dispute resolution. These included episcopal courts (bishops wielded spiritual authority and from the time of Constantine were recognized as civil magistrates), the more or less informal courts of local lay magnates, and holy men (notably stylite monks). In many cases, both litigants would agree to submit to the arbitration of a lay or clerical arbitrator, thus avoiding the official state court system.

(Simonsohn, 2011) Religious affiliation was an important factor in determining under whose authority any individual was, but it was a network of fluid and overlapping jurisdictions, in which individuals often had the opportunity to exercise choice (what legal scholars call 'forum shopping').

Religious affiliation was of course not the only factor determining legal status of an individual. This is particularly true in Latin Europe in the 5th to 8th centuries, as new kingdoms emerged in what had been the western empire, and as their kings issued (or had written) a series of law codes in which law and jurisdiction depended less on territorial limits of any kingdom and more on the legally or ethnically defined status of individuals as 'Romans', 'Goths', 'Franks' etc.. (Berman,1983: 49-68) Which law applied to any individual and how it applied depended not (or not only) in which territory one lived but on a variety of social factors: free or unfree, lay or cleric, Roman or Frank. In the Salic Law, for example, the wergild (compensation) for killing a man depends on the status of the victim: 100 shillings for killing a Roman; 200 for a free Frank, a ‘Barbarian living under Salic Law' or a woman too 
old to bear children; 300 for a Roman who 'eats at the king's palace'; 600 for a young boy, a woman of child-bearing age, a count, or a man in the king's service; 700 for a pregnant woman. (Fischer Drew, 1991)

Much ink has been spilt over how to interpret such laws. While often the kings who were at the origin of these codes claimed to be recording the ancestral laws of their gentes, we in fact find a mixture of Roman and Germanic elements in many of these codes. What was the purpose (or the purposes) of having them written down? To reconcile competing or overlapping systems of justice, Roman and 'barbarian'? To give prestige to the gens and its king, now in possession of their own written law? To diffuse or discourage traditional forms of private or clan justice (through vengeance and vendetta), by replacing them with tariffed menus of wergild? To offer protection to those (in particular churchmen) who did not benefit from family and clan solidarity and who thus may have been more vulnerable to violence? No doubt each of these motivations was behind one or another of these compilations. But it is difficult to know to what extent they were used or applied in practice.

In a legal culture in which social, ethnic, political and economic factors affected the legal status of individuals, religious affiliation was one discriminating factor among many. With the notable exception of laws concerning Jews in Visigothic Spain, these codes say little or nothing about religiously defined groups. For the Early Middle Ages the principal source of laws discriminating along religious lines are the canons issued by church councils, which in many cases reiterate earlier Roman law (such as the stipulations of the Theodosian Code). For example, the prohibition of intermarriage between Christians and Jews, promulgated in the Theodosian Code (CTh 3.7.2), is reiterated by the councils of Orleans 2 (in 533), Claremont 1 (535) and Orleans 3 (538). Various laws in the Theodosian Code had prohibited Jews from circumcising their Christian slaves: the third council of Orleans reiterates this prohibition and extends it more generally to the mistreatment of Christian slaves; the fourth council of Toledo (633) prohibits Jews outright from owning Christian slaves, a prohibition which would be 
adopted into Gratian's Decretum in the 12 th century. ${ }^{\text {iv }}$ Here again, these conciliar canons pose problems of interpretation, as we have little evidence of the extent to which they were respected. For example, does the reiteration of the prohibition of marriage between Christians and Jews at three councils in the 530s imply that such marriage was taking place and that successive councils were unsuccessful in stopping the practice? Or is it merely an instance of one council adopting a measure from an earlier one, whether or not it corresponded to real practice? Similarly, repeated laws against Jews owning Christian slaves may say more about the zeal of the Christian legislators than about social realities. At some of these councils, only ecclesiastics (in particular bishops) were present; in others, kings took an active role. To what extent does this imply royal sanction for the canons of these councils?

In sum, in a period for which there are few sources concerning the functioning of justice and the place of non-Christians (in particular Jews) in the Latin Europe, the collections of laws, whether royal or conciliar, are among the most important and abundant sources. Yet the sources are difficult to interpret and have given rise to widely divergent readings concerning the place of Jews in the legal systems (and more broadly in the societies) of Latin

Christendom. ${ }^{\mathrm{v}}$ In the absence of Hebrew sources, we know nothing about whether or to what extent Jewish communities enjoyed judicial autonomy within the new polities of the Latin west; the laws say little about Jews' access to justice.

\section{The expansion of Islam and the creation of a protected and subordinate dhimmi} status

The arrival of Islam added another jurisdictional layer to the legal pluralism that Mediterranean and Near-Eastern societies had known under Romano-Byzantine and Persian rule. In the wake of the Muslim conquests, the official Roman justice system ceased to exist in the conquered areas. This tended to enforce the role of bishops as judges for disputes (both 
civil and religious) between Christians. Yet there were other, competing authorities, both Christian and non-Christian, lay and ecclesiastical. Christians could decide to take their cases to a local prominent Christian layman, to a monastery, to a stylite hermit. Or they could take their litigation to a Muslim $q \bar{a} d \bar{l}$. We know about all this principally from the texts in which episcopal authorities (bishops or those speaking for the bishops) complain of these practices or try to prohibit them. We have similar testimonies concerning Jews. Already in the late Roman periods, we find texts in which the Jewish patriarch attempts to prohibit Jews from taking their cases to Roman courts. In similar ways, various medieval responsa prohibit Jews from approaching Muslim judges. The more shrill these proclamations, and the more draconian the punishments for them (excommunication in some cases), the clearer it is that these restrictions are little respected. (Simonsohn, 2011)

While Muslim administrators and jurists incorporated and adapted legal traditions from their predecessors, notably the Persian and Byzantine empires, the corpus of Persian or Roman law was never seen as legitimate in and of itself and very little of it was ever translated into Arabic (in contrast with the massive translation of scientific and philosophical works during the 'Umayyad and especially the Abbasid dynasty). The backbone of Muslim law was the

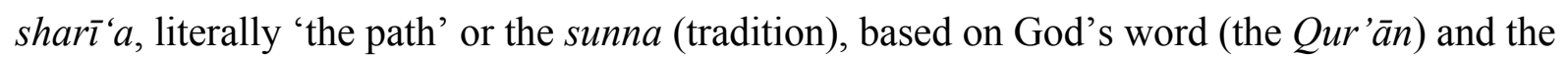
sayings attributed to the Prophet Muhammad (as transmitted in the hadith). Scripture and law are inextricably linked for Muslims as for Jews and Christians: Muslim writers often refer to Judaism and Christianity (or their scriptures) as Ahl al-Kitab (people of the book), and also to sharì'a Musa (the way of Moses) and sharì'a al-Masīh (the way of the Messiah), and Jewish and Christian authors themselves at times refer to their own scriptures as sharì'a. (Hooker, M., 'Shari'a', EI2 9:331-38) While there was only one God and hence one dinn, there were many 'paths' (sharī'a-s) towards him, as the Qur'ān affirms. (Quran 5;48) ${ }^{\mathrm{vi}}$

During the 7th and 8th centuries, the study of law, fiqh, emerged in the new urban centres of the Islamic empire, based on the Qur'àn, hadith, and also the collected opinions ( $\left.r a^{\prime} y\right)$ of 
legal scholars - the latter, of course, often informed by pre-Islamic (notably Persian and Byzantine) concepts of law and justice. ${ }^{\mathrm{vii}}$ Yet in the early 9th century, one prominent jurist, al-Shāfi'ì (d. 820, founder of the eponymous Shäfi' '̄ school, one of the four madhhabs of classical Sunni Islam), declared that $r a^{\prime} y$, the mere opinion of a jurist (however eminent) was insufficient as a basis for law, which had to be built on the pillars of Qur'ann and hadith. This point of view-also directed against Shi'ite tendencies to attribute less significance to the Sunna in favour of Imams' rulings - became dominant in the east. It led to a flurry of activity among jurists who needed to find (or invent) hadith to justify their legal opinions. (Fierro, 1991: 119-132) In the Muslim west, however (the Maghreb and Muslim Spain), the 'people of the hadith" (ahl al-hadith) did not prevail over those of opinion (ahl al-ra'y): the legal opinions of Malik, founder of the Malikite madhhab, laid out in his Mutawwana, formed the basis of later reflection by jurists, and the disciplines of fiqh and hadith remained largely distinct and separate, unlike in the Orient.

Fiqh developed a clearly-defined status for Jews, Christians and at times other non-Muslims as $d$ himmī-s, or protected persons. ${ }^{\text {viii }}$ Although the Qur'ān does not clearly establish the legal framework for non-Muslims within the dār al-islām, it declares that the Muslim must not force the 'peoples of the book' (ahl al-kitāb, the Jews and Christians) to convert. By contrast, he may oblige them to recognize the superiority and suzerainty of Muslim authority and to pay 'humbly' the jizya, the capitulation tax. (Qur'ān 9:29) During the conquests of the first Islamic centuries, the victorious Muslims gave guarantees to the conquered peoples, granting them legal autonomy and freedom of worship. According to certain chroniclers, restrictions were sometimes among the conditions of surrender applied to the defeated Christians. This is apparent in the Pact of 'Umar, which, according to Muslim tradition, the second caliph, 'Umar ibn al-Khattab (634-644), imposed on the Christians of Syria. In fact these restrictions were imposed gradually, throughout the first Muslim century, and expanded under 'Umar II (717-720). (Fattal, 1995: 60-69; Oulddali, 2012) The first author to give us a full version of 
the Pact of 'Umar is the Andalusian traditionist al-Turtūshī (d. 1126) in his Siraj al-mulūk. In that text, the Christians of Syria send a missive to Caliph 'Umar to remind him of the pledge they made at the time of their surrender. They present a long list of prohibitions that they agreed to respect: on building new churches and monasteries, teaching the Qur'ān, wearing 'Muslim' clothing or turbans, bearing arms, and so on. A numbers of these measures were aimed at limiting or proscribing the public expression of Christianity. Hence the Christians pledged not to put crosses on their churches, not to display their scriptures in public, not to participate in certain public processions, not to pray in a noisy or ostentatious manner, not to ring their bells too loudly. (Fattal,1995: 62)

Tradition attributed that pact to 'Umar, general during the conquests and the second caliph, probably to grant authority to a status that took definite shape only slowly in the early Muslim centuries. It was during the 8th and 9th centuries CE that the Umayyad, then the Abbasid, caliphs and jurists defined and circumscribed the status of the dhimmī. By paying the jizya, the dhimmi-s marked their submission to Muslim authority and as a result enjoyed its protection. Land owners also paid the kharāj, a property tax higher than the one Muslims had to pay. Dhimmī men could not marry Muslim women, though Muslim men could marry Jewish or Christian women. The theoretical restrictions were not uniformly respected, however. Far from it: many churches and synagogues were built in Muslim countries; the clothing prohibitions were applied very unevenly, and a number of Christians and Jews occupied positions of authority in the entourage of princes. Yet in fact when one looks closely at the early legal texts or chronicles from both the Mashrek and the Maghreb, there is little evidence for a standard, uniform dhimmī system, but rather a wide variety of local adaptations, as recent scholarship has shown. Even for the jizya, often presented as the linchpin of this system, there are significant variations. The classic jizya model (to the extent one ever existed) was in fact a product of the Abbasids: in the Umayyad period, fiscal policy towards conquered Christians was quite varied and often based on practical considerations 
and respect for local traditions. The jizya could at times be imposed on individuals but also on groups; sometimes it was levied on lands (blurring the distinction between jizya and kharaj). (Carmona, 2013) The jizya was not systematically levied either in 7th-century Egypt or in 9th-century Sicily. (Nef, 2013) 15th-century Tlemcen mufti Qāsim al-’Uqbānī was asked whether the jizya is to be imposed on all Jews or only those who live in the cities; as one might expect, he affirmed the principle that it applied to all male Jews who lived as dhimmis under the protection of Muslim rulers: but the very fact that the question was raised suggests that rural Jews were often in practice exempted from paying. (Voguet, 2013)

Dhimmī communities enjoyed a certain juridical autonomy: bishops or other Christian officials judged cases between Christians and the same applied to Jews; only cases involving a Muslim would in theory be brought to a Muslim court. Yet in Egypt, qāạ̄ Khayr bin Nu'aym (751-53) judged cases between dhimmīs — and accepted their testimony, after having verified with their fellow Jews or Christians that they were trustworthy; one of his successors, Muhammad bin Masrūq al-Kindi ( $q \bar{a} d \bar{l}$ from 793 to 800), received Christians in the main mosque of Cairo to hear their cases. (Kindi, 2012: 41, 108, 156) Other jurists sought to safeguard dhimmīs judicial autonomy: Ifriqiyan jurist Abu Muhammad Abdullah ibn Abi Zayd al-Qayrawani (922-996) posits that only if both Christian parties and their bishop agree to submit a case to a Muslim qā $d \bar{\imath}$ should the latter hear the case (which otherwise is under the jurisdiction of the bishop). ${ }^{\text {ix }}$ Shafi ite jurist al-Māwardī (from Basra, d. 1058), for example, recommends not intervening in the internal affairs of dhimmiss, who, he affirms, have the right to settle their intra-communal conflicts under their own jurisdictions, which function independently. If, however, they decide to approach a Muslim tribunal or solicit the arbitration of a $q \bar{a} d \bar{l}$, they cannot be prevented from doing so. The $q \bar{a} d \bar{l}$ may hear the case on the condition that he renders a judgement according to Islamic law; in this case the penalties provided by Islamic law, including corporal punishment, will also be applied to them. ${ }^{\mathrm{x}}$ Other jurists similarly affirm that judicial autonomy should be respected, but that some cases may 
be heard by Muslim qāọīs. Malakite jurist Ibrāhīm Ibn 'Abd al-Rafī' (d. 1332) upholds the same principle of the right of dhimmīs to settle internal disputes by means of their own laws. He affirms that Muslim justice should not encroach upon matters pertaining to dhimmī courts of justice since the autonomy of these courts is one of the guarantees accorded to nonMuslims. Nevertheless, if the dhimmī plaintiffs refer the matter to the $q \bar{a} d \underline{\imath}$, he has the option of accepting and settling their dispute on the condition that he does so with recourse to Muslim law. Yet the very fact that he insists that the $q \bar{a} d \bar{\imath}$ must apply Muslim laws suggests that in some cases dhimmīs may have expected Muslim officials to judge according to Christian or Jewish law. ${ }^{\mathrm{xi}}$ Clearly, some Jews and Christians preferred taking even their internal disputes to a Muslim $q \bar{a} \underline{d} \bar{l}$, and that for at least some of them in some cases, forum shopping was a real possibility.

Between the 4th and 6th centuries, as we have seen, the concept of 'religion' as we know it emerged, and through the pronouncements of bishops, rabbis and theologians - and through the laws preserved in compilations such as the Theodosian Code and the texts of Justinianboundaries were erected between groups identified as 'Christian', 'Jewish' and 'heretic'. By the time Islam emerged in the Arabian peninsula, boundaries between various Jewish and Christian confessional groups (though at times shifting) were established and known. Thus the Qur'ān recognizes Jews and Christians as distinct groups, both of which (as Ahl al-Kitab) have their own scripture; Muslim jurists developed the notion of dhimmi and defined their role in Muslim society. While practices varied widely, in theory practitioners of fiqh from Baghdad to Cordoba recognized the judicial autonomy of dhimmī communities and limited the jurisdiction of Muslim qā dīs over dhimmīs. ${ }^{x i i}$ This clear theory of subordination and autonomy contrasts with the somewhat confused picture of the Jewish position within Latin Christendom in the Early Middle Ages, as we have seen. It is only with the renewed study of law in the 11th and 12th centuries that jurists attempt to define the place of Jews (and Muslims) in Christian society. 


\section{The 'rediscovery' of Roman law and the refoundation of canon law (11th-12th centuries)}

The 11th and 12th centuries, in Latin Europe, witnessed what many scholars have referred to as a 'renaissance' in the study of law. This movement, associated in particular with the schools of law in Bologna (which would emerge at the turn of the 13th century as Europe's first university), involved the commentary of key texts of Roman law-in particular the code of Justinian. The elaboration of civil law was accompanied in Bologna by the codification and study of canon law. The two developed in parallel and to a certain extent in competition. At issue were the relations between ecclesiastical and lay power and authority and the definition of orthodoxy. This context is essential to the development of law in the period and four closely related issues need to be kept in mind: the struggle between Empire and Papacy (what is traditionally referred to as the 'investiture controversy'), the birth of scholasticism, the emergence of a highly trained clerical elite (which came to dominate both ecclesiastical and lay administrations) and the birth and growth of heretical movements within Latin Christendom (and organized efforts to combat them). These developments, which together comprise what Harold Berman has called the 'Papal Revolution', transformed European conceptions of law and religion and of the relations between the two. (Le Bras et al., 1965)

A consequence of the reform movement was a redefinition of the political legitimacy of monarchy. Until the 11th century, kings and emperors were portrayed as the anointed of God, holy, crowned by Christ, His agents on earth who knew no equal; their consecration (through the anointment that accompanied coronation ceremonies) placed them not only above the laity but also the churchmen. Yet starting in the 11th century, ecclesiastical reformers increasingly challenged this ideology, affirming that the Pope was the true 'Vicar of Christ'. While kings and emperors never gave up entirely on the sacred nature of their power, they now sought 
other sources of legitimacy, in particular in law: putting less of an emphasis on sacral kingship, they embraced legal monarchy, for which they (or their jurists) turned to the legal traditions of Rome, in particular the compilations made under Justinian.

The renewal of Roman jurisprudence met the practical needs of a rapidly urbanizing society and bureaucracy. While it was supporters of the empire who first embraced Justinian's work, interest quickly exceeded the context of disputes between papacy and empire. Bolognese lawyers tried to order society along rational and universal standards. Justinian himself had tried to coordinate and unify the Roman law; he affirms that there is no contradiction in his legal works. ${ }^{\text {xii }}$ This assertion made sense to 12 th-century readers: like the Bible, Roman law brooked no contradiction, and the work of a legist (like that of a theologian) is to find clever explanations to show that any conflict is apparent, that the laws of Justinian (like the biblical doctrines) can be (to paraphrase Abelard) 'diversa sed non adversa', 'different, but not adverse'.

In a way, these lawyers were performing the work that Justinian himself had ordered to be done: to accept his laws and to enact and explain them, so that they may better govern the empire. Indeed, as Harold Berman has emphasized, it is the 12th- and 13th-century commentators on these texts who first conceived them as a unified 'body' and called them the Corpus iuris civilis. (Benson, 1982: 363; Berman, 1983) 12th-century jurists tried to explain the Justinian code by referring only to other Roman legal texts, straining to impose order these disparate texts, or rather (they would say) to discover and restore the underlying order. If the emperor is the supreme legislator, the source of law is not arbitrary authority: it is justice (aequitas), which the emperor puts into place and interprets, that is the source of law (ius); this justice (for many jurists) is identical to reason (ratio). Roman law is a rational order that should be restored. 'For a civil and religious society in which different customs prevail ... the Corpus provides a uniform, rational law' (Winroth, 2002) 
At the turn of the 12th century, the papacy and its advocates had no systematic opus of canon law to oppose to the Justinian corpus. Canon law was based on a broad and diverse collection of texts: papal bulls, canons of Church councils, writings of the Church fathers, and biblical injunctions. Several 11th- and 12th-century canonists (notably Burchard of Worms and Ivo of Chartres) had compiled some of these materials into thematically oriented collections. But it was in Bologna in the 12th century that the most thorough and systematic attempt to forge a summum of canon law was undertaken: the Concordia discordantium canonum, better known as the Decretum. This work is traditionally attributed to Johannes Gratiani, or Gratian, about whom we know very little. Recent work, notably that of Anders Winroth, has shown that the Decretum was most probably a collaborative effort and that the text evolved over the course of several decades). In any case, the Decretum was an immense, thematically organized, encyclopaedic compilation of canon law that quickly became the manual of canon law, indispensable both for the church officials who applied canon law (and rendered judgments based on it) and for the masters who taught it, in Bologna and elsewhere.

This fundamental transformation of canon law has long been recognized as a watershed in how Europeans conceived 'religion'. For legal historian Rudolph Sohm, the 'old Catholic' church law (as seen in particular in the penitentials) was essentially spiritual and sacramental; only with Gratian did it become 'legal' in the modern sense. (Tolan, 2003; Berman, 1983: 201-3) Similarly, for Arnold Angenendt the scholastic revolution in both law and theology was key factor in the transformation of European Christendom from an 'archaic' religion in the Early Middle Ages (based on formulaic ritual and closely associated with magic) to a more modern conception of religion (based on individual spirituality and reasoned theological inquiry). (Angenendt, 1997) ${ }^{\text {xiv }}$ While both Sohm's and Angenendt's analyses have been contested and nuanced, they are no doubt correct in seeing the intellectual and textual revolution of the scholastic age as introducing a fundamentally new conception of religion. 
While the canon law of Gratian could be seen in some ways as a defensive response to the development of pro-imperial Roman law traditions, in many respects the two movements shared the same goals: taming the dense thicket of laws, decrees, privileges and rules, turning it into an orderly garden, reflection of divine reason and of the power of his earthy agents, whether emperors and kings or popes. In many ways, of course, this was an intellectual game or a dream, far from the realities of law: these same emperors, kings and popes issued a bewildering variety of very specific laws and privileges to cities, dioceses etc. Yet jurists still dreamed of harmonizing law in accordance with rational principles and expressed their frustration with local or regional exceptions to the overarching schemes of Roman and canon law: the canonist Huguccio dubbed the Lex lombarda (Lombard Law) faex lombarda (Lombard shit). (Benson, 1982)

How does Gratian present the relations between these different types of law and define hierarchies among them? In his Tractatus de legibus, he affirms:

The Human Race is ruled by two things: namely, natural law (naturalis ius) and customs(mores). The law (ius) of nature is what is contained in the lex and the Gospel. By it, each person is commanded to do to others what he wants done to himself and is prohibited from inflicting on others what he does not want done to himself. As Christ says in the Gospel: 'So in everything, do to others what you would have them do to you, for this sums up the Law and the Prophets'. All laws (leges) are either divine or human. Divine laws are based on nature, human laws on customs. For this reason human laws may differ, because different laws suit different peoples. Fas is divine law; ius is human law. ${ }^{\mathrm{xv}}$

In this brief passage, Gratian attempts to cut through a Gordian knot of legal complications regarding the legitimacy of competing systems of law and the primacy of Church or canon 
law, which is both consistent with other systems of law and takes priority over them in certain key cases of difference. What we commonly call 'laws' (leges), and what Gratian here qualifies as 'human laws', are merely custom recorded in writing. Divine law and natural law both correspond to ius. Gratian has in mind not only the conflict between Empire and Church, but also centuries of reflection by theologians and jurists on the relations between Christian and non-Christian laws. Augustine, among others, posited a succession of ages. First 'before the law' (from Adam to Moses) is the age in which humanity is ruled by 'natural law', as dictated by human reason. Under natural law humanity progressed and became ready to receive God's law through Moses, marking the beginning of the second age (from Moses to Christ), 'under the law' (even though most of humanity, ignoring Mosaic law, still followed natural law). Finally, humanity progresses to the point where it is ready to receive redemption through Christ's incarnation, which marks the beginning of the third and final age 'under grace'. While Augustine (and after him 12th-century theologians such as Hugh of St Victor) emphasize the progression between the three laws, each more perfect than its predecessor, Gratian emphasizes the essential harmony between the three. While natural law, instituted at creation, is the oldest of the three, nothing in divine law contradicts it. What divine law contains beyond natural law are the mystica, mysteries or sacraments, which man could not have discovered by simple reason. For example, the duty of circumcision or the prohibition of pork; these are mystica contained in the Law of Moses. And the Christian Law of the Gospels contradicts neither natural nor Mosaic law: Christ himself affirmed that he came not to destroy the law but to fulfil it [Matt. 7:15]. Thus, for Gratian, when the Church replaced circumcision by baptism this was not a modification of the immutable divine law, but simply the spiritual observation of a law that had heretofore been interpreted literally. Divine law hence contains all of natural law; anything that goes against natural law is necessarily against divine law as well. Instead of trying to exclude Justinian from divine law, he envelops and subordinates him: Roman law is useful and valid, but only in as much as it corresponds to the 
principles of justice incarnated in natural law. The authority of Roman law derives from its adherence with the principles of natural and divine law, not from its antiquity or its association with the Empire.

For Gratian, and for canonists of the following centuries, these principles had important consequences for the legal status and legitimacy of non-Christians both within and outside of Christendom. The legitimacy of Mosaic law implied a role for Jews living within Christian society. In this, again, Gratian is very much in the continuity of traditions grounded in Roman law and theorized by Augustine (as noted above), among others.

This vision of Judaism bowed and subservient pervades theological and legal texts of the period. Throughout Europe, communities of Jews lived in the cities (and in some areas in the countryside) and often played important roles in trade and, increasingly, in finance. Various European rulers issued laws guaranteeing safety and often some degree of legal autonomy to these Jewish communities. Pope Callixtus II (1119-1124) issued a bull Sicut Judaeis, which offered few specific protections to Jews living within Christian society. Callixtus' letter does not survive, nor does that of his successor Eugenius III (1145-1153), but both are referred to by Pope Alexander III, who issued his own bull, Sicut Judaeis, sometime between 1159 and 1181, in which he prohibits Christians from forcing Jews to convert or imposing penalties on those who do. He further bars Christians from injuring Jews or taking money from them, disrupting Jewish festivals, exacting additional services or desecrating Jewish cemeteries to extort money. ${ }^{\mathrm{xvi}}$ Later popes were to reissue this bull, sometimes with minor variations.

Dozens of the legal texts compiled by Gratian in his Decretum provide concrete examples of the subordinate but protected role of assigned to Jews in Christian society. While the Church claimed no jurisdiction over Jews, it did attempt to regulate and limit Christian interaction with Jews, prohibiting Christians from sharing meals with Jews or having sexual intercourse with them - much less marry them. Jews were not to own Christian slaves (a rule later 
interpreted as a ban on the employment of Christian servants); they were not to exercise authority over Christians. ${ }^{\text {xvii }}$ In the judicial landscape of medieval Europe, multiple systems of justice overlapped (and sometimes were in outright rivalry with each other): seigniorial courts, royal courts, municipal courts, ecclesiastical courts, and rabbinical courts (which treated disputes within the Jewish communities). In theory, Jews were prohibited from bearing witness against Christians or exercising any jurisdiction or authority over them: this principle is found in Roman law, in canon law and in many texts of civil law. Yet in fact, throughout Europe we find numerous laws that allow Jews to bear witness against Christians in disputes concerning them and that allow disputes between Jewish and Christian individuals to be judged by a mixed group of Christians and Jews. As in Rome and Byzantium, these restrictive laws are often reissued and reiterated, suggesting that they were enforced only sporadically.

In Christian terms, this subservient place of Jews in society corresponds to the distinction of different laws in three ages: if in the first age, ante legem, the law of nations (lex gentium) was universal, it is superseded, but by no means nullified, by the revelation of the new law of Moses (lex Moysi). For jurists from Gratian to Grotius and beyond, natural law, seen as the source of lex gentium, remains the basis of political and legal legitimacy of non-Christian nations: from the 13th century onwards, jurists debated over when and to what extent Christian rulers could forcibly take power from non-Christians. While their responses vary, on the whole it was only the breaking of natural law (through human sacrifice, for example, or through persecuting Christians) that justified Christians taking over their lands. We have seen that with the advent of the lex Christi, the lex Moysi is subsumed and perfected under the new law, yet Jews enjoy a precarious toleration for their continued respect of the lex Moysi.

What about the Muslims (or 'Saracens', the term used by medieval authors, including jurists)? (Tolan, 2002) As gentes who had received neither the Mosaic revelation nor the Gospel, they were subject to natural law or lex gentium. Yet many Latin authors were aware that they had 
their own scriptures or law, often referred to as the 'law of the Saracens' (lex Sarracenorum) or the 'law of Muhammad' (lex Mahumeti). While Latin Christians had a coherent vision of Judaism, where a legitimate but surpassed revelation granted them a tolerated but inferior role in Christian society, there was no coherence between Latin Christians' theological vision of Islam and the role granted to Muslims living in Christian societies. Just as the term $\operatorname{sharī~}^{\prime} a$ is used by contemporary Arab writers (Jews, Christians and Muslims) to mean at the same time 'scripture', 'law' and 'religion', Latin writers use lex to refer to scripture (bible or Qur'ān) and to faith community (of Jews, Christians or Muslims). This use of the terms lex Mahumeti and lex Sarracenorum underlines the profound ambivalence of Latin authors towards Islam and the Qur'ān. While polemicists attacked the Qur'ān and denounced Islam as heresy, they also begrudgingly granted it the status of law and scripture. ${ }^{\text {xviii }}$

While theologians increasingly painted Islam as heresy, canon law granted Saracens a legal status similar to that of Jews, indeed often simply adding to existing laws concerning Jews the provision that the law applied also to 'Saracens' or 'pagans'. For example, when in 1179 the Third Lateran Council reissued the prohibition of Jews having Christian servants, it was specified that the prohibition applied to 'Jews and Saracens' ${ }^{\text {xix }}$ Subsequently, the decretal collections of canonists Bernard of Pavia (compiled between 1188 and 1192) and Johannes Gallensis (between 1210 and 1214) grouped together decretals concerning Jews and Saracens under one heading. (Friedberg, 882) The Fourth Lateran Council imposed distinctive dress on both Jews and Saracens and prohibited both from holding public office or exercising any position of authority over Christians. These principles were consistently reiterated in subsequent law texts, both ecclesiastical and secular - though they were frequently ignored in practice. 
The legal revolution in Europe between the 11th and 13th centuries thus saw the affirmation of a number of fundamental principles which were to permeate European legal discourse in the following centuries and which are still central to Western notions concerning 'law' and 'religion' - including, of course, the methodological suppositions of many historians and anthropologists. For legal scholars as for theologians in this period, God established a rational order to his creation, an order which man, through his God-given gift of reason (and in spite of his imperfection) can strive to understand. The harmony of the foundational texts and principles of law, like those of Christianity, were a matter of faith. This unified theory of ius as an expression of God's rational order of the universe evolved in a fragmented legal landscape, where diverse legal fora existed and competed (episcopal, seigniorial, papal, royal, municipal, rabbinical, ducal etc.).

Like a tree whose growth rings testify to years of drought or flood, fire or cold, our 21stcentury notions of 'religion' and 'law' bear the marks of the struggles in which they were born and in which they evolved. The four periods examined here are crucial to the evolution of both concepts. It was in the 4th- and 5th-century Christian Roman Empire, that the concept of 'religion' as we know it emerged, first to define Christianity, then to qualify the rival 'religions' of Hellenism and Judaism; and a key element in defining and delimiting these 'religions' is found in laws, notably those of the Theodosian Code. Yet we also saw that law was far from monolithic, and that in the late Roman Empire (and even more so in the kingdoms that succeeded the Empire in the west), judicial pluralism was the rule, as individuals and groups negotiated between competing jurisdictions. We examined Arabic concepts of din, sharì'a, fiqh etc., and saw how closely linked notions of law and religion were in early Muslim societies; we also saw how fiqh clearly defined the protected and subordinate status of Jews and Christians and granted them limited judicial autonomy. 
Finally, we have seen how the 12th-century revolution in European legal studies fundamentally altered our notions of both law and religion.

Historians, anthropologists, sociologists and others should thus keep in mind that the terms 'law' and 'religion' are packed with strata of implications that have accumulated over the centuries: neither term translates easily into languages that were not shaped by these events. Anthropologists have of course long been aware of this and have struggled to define 'religion' or to propose alternate terms. (cf. Morris, 2006: 1-13; Obadia, 2007) But often the alternate terms are even more problematic: 'faith' or 'belief' for example, emphasize a phenomenon that is at the heart of the definition of Christianity or Islam, but is only part of it - and is not the defining or most salient feature of other commonly-identified 'religions'. And of course faith and belief are important to many aspects of our lives that we do not recognize as pertaining to the realm of the religious. 'Cult', 'rite' and other terms pose similar problems. The solution is perhaps not to find some euphemistic substitute for our loaded terms law and religion, but to bear in mind that these terms, like so many others we use, are far from universal, and that to understand them one has to comprehend how they have evolved over the centuries.

\section{References}

Discourses of Purity in Transcultural Perspective, (2014), Nikolas Jaspert et al, eds., Dynamics in the History of Religions, Brill, Leiden.

Le Code Théodosien: Livre XVI (2005), J. Rougé (trans.), Cerf, Paris.

The Etymologies of Isidore of Seville (2006), S. Barney (trans.), Cambridge University Press, Cambridge/New York, NY. 
Jews in Early Christian Law: Byzantium and the Latin West, 6th-11th Centuries (2013),

Religion and Law in Medieval Christian and Muslim Societies, J. Tolan (ed.), Brepols, Turnhoult.

Angenendt, A. (1997), Geschichte Der Religiosität Im Mittelalter, Primus Verlag, Darmstadt.

Bendlin, A. (2013), 'Migration, Religion in Der Diaspora Und Die Antike Großstadt Als Religiöser Interaktionsraum', http://cms.uni-konstanz.de/veranstaltungen-2013/religioeseminderheiten/

Benson, R. (1982), 'Political Renovatio: Two Models from Roman Antiquity’, in Renaissance and Renewal in the Twelfth Century, R. Benson \& G. Constable (eds), Harvard University Press, Cambridge, MA, pp. 339-386 (363).

Benson, R. (1982), 'Political Renovatio: Two Models from Roman Antiquity', in Renaissance and Renewal in the Twelfth Century, G. Constable, R. Benson \& C. Lanham (eds), University of Toronto Press, Toronto, pp. 339-386.

Berman, H. J. (1983), Law and Revolution: The Formation of the Western Legal Tradition, Harvard University Press, Cambridge, MA.

Boyarin, D. (2004), Border Lines: The Partition of Judaeo-Christianity, University of Pennsylvania Press, Philadelphia, PA.

Boyarin, D. (2004), 'The Christian Invention of Judaism: The Theodosian Empire and the Rabbinic Refusal of Religion', Representations, no. 85, pp. 21-57.

Burman, T. E. (2007), Reading the Qur'an in Latin Christendom, 1140-1560, University of Pennsylvania Press, Philadelphia, PA.

Carmona, A. (2013), 'Doctrina Sobre La Ğizya En El Occidente Islámico Pre-Moderno’, in The Legal Status of Dimmi-S in the Islamic West (Second/Eighth-Ninth/Fifteenth Centuries), M. Fierro \& J. Tolan (eds), Brepols, Turnhoult, pp. 91-110. 
Çelebi, E. (2012), Conditions for the Application of Islamic Law in Disputes between the Protected People, or between Christians and Muslims. http://www.cntelma.fr/relmin/extrait252603/.

Cohen, J. (1999), Living Letters of the Law: Ideas of the Jew in Medieval Christianity, University of California Press, Berkeley, CA.

Delmas-Marty, M. (2006), Le Pluralisme Ordonné, Seuil, Paris.

Delmas-Marty, M., Norberg N. (2009), Ordering Pluralism: A Conceptual Framework for Understanding the Transnational Legal World, Hart Publishing, Oxford/Portland, OR.

Drake, H. A. (2000), Constantine and the Bishops: The Politics of Intolerance, Johns Hopkins University Press, Baltimore, MD.

Drew, K. F. (1991), The Laws of the Salian Franks, University of Pennsylvania Press, Philadelphia, PA.

Elm, S. (2012), Sons of Hellenism, Fathers of the Church: Emperor Julian, Gregory of Nazianzus, and the Vision of Rome, University of California Press, Berkeley, CA.

Fattal, A. (1995), Le Statut Légal Des Non-Musulmans En Pays D'islam, Dar El-Machreq Sarl, Beirut.

Fierro, M. (1991), 'El derecho malikí en al-Andalus: siglos II/VIII-V/IX', Al-Qantara, vol. XII, pp. 119-132.

Fredriksen, P. (2008), Augustine and the Jews: A Christian Defense of Jews and Judaism, Doubleday, New York, NY.

Friedberg, A. (ed.) (1882), Quinque compilationes antiquae, nec non Collectio canonum lipsiensis, Berhard Tauchnitz, Leipzig.

Juster, J. (1914), Les Juifs Dans L'empire Romain; Leur Condition Juridique, Économique Et Sociale,: P. Geuthner, Paris. 
Kindi, Muhammad Ibn-Yusuf (2012), Histoire Des Cadis Égyptiens, M. Tillier (trans.), Inst. Francais d'Archéologie Orientale, Cairo.

Kuttner, Stephen (1983), 'The Revival of Jurisprudence', in Renaissance and Renewal in the Twelfth Century, R. Benson \& G. Constable (eds), Harvard University Press, Cambridge, MA, pp. 299-323.

Le Bras G., Lefebvre, C. \& Rambaud, J. (1965), L'âge Classique, 1140-1378: Sources Et Théorie Du Droit, Histoire Du Droit Et Des Institutions De L’Église En Occident, Sirey, Paris.

Linder, A. (2006), 'The Legal Status of the Jews in the Roman Empire', in The Cambridge History of Judaism, Vol. IV, the Late Roman-Rabbinic Period, S. Katz (ed.), Cambridge University Press, Cambridge, pp. 128-173.

Magdelain, A. (1978), La Loi À Rome: Histoire D’un Concept, Belles Lettres, Paris.

Magdelain, A. (1990), Ius Imperium Auctoritas: Études De Droit Romain, Boccard i.a., Paris. Morabia, A., Arnaldez, R. \& Morabia, A. (1993), Le Gihâd Dans L'islam Médiéval: Le 'Combat Sacré' Des Origines Au Xiie Siècle, A. Michel, Paris.

Morris, B. (2006), Religion and Anthropology, Cambridge University Press, Cambridge.

Mousourakis, G. (2007), A Legal History of Rome, Routledge, London/New York, NY.

Muldoon, J. (1979), Popes, Lawyers, and Infidels: The Church and the Non-Christian World, 1250-1550, University of Pennsylvania Press, Philadelphia, PA.

Nef, A. (2013); 'Le Statut De Dimmī-S Dans La Sicile Aghlabide', in The Legal Status of Dimmī-s in the Islamic West (Second/Eighth-Ninth/Fifteenth Centuries), M. Fierro \& J. Tolan (eds), Brepols, Turnhoult, pp. 111-30.

Nemo-Pekelman, C. (2010), Les Juifs Et Le Droit À Rome (Ive-Ve Siècles), Honoré Champion, Paris. 
Nemo Pekelman, C. (2010), Rome Et Ses Citoyens Juifs (4e-5e Siècles), Champion, Paris.

Obadia, L. (2007), L'anthropologie Des Religions, La découverte, Paris.

Oulddali, A., (2013), 'In Which Condition the Qadi May Intervene in Dhimmī Affairs?', http://www.cn-telma.fr/relmin/extrait252252/.

Māwardī 'aī̄ B. Muhammad, Resolving Conflicts between Dhimmīs. http://www.cntelma.fr/relmin/extrait136579/.

Oulddali, A. (2012), 'The Pact of 'Umar', http://www.cn-telma.fr/relmin/extrait1068/.

Pospisil, L. J. (1971), Anthropology of Law: A Comparative Theory, Harper \& Row, New York, NY.

Pucci Ben Zeev, M. (1995), 'Did the Jews Enjoy a Privileged Position in the Roman World', Revue des etudes Juives, no. 154, pp. 23-42.

Sapir Abulafia, A. (2011), Christian-Jewish Relations, 1000-1300: Jews in the Service of Medieval Christendom, Longman, London.

Schiavone, A. (2005), Ius : L'invenzione Del Diritto in Occidente, G. Einaudi, Turin.

Signer, M. (1999), 'Jews and Judaism', in Augustine through the Ages: An Encyclopedia, A. Fitzgerald (ed.), William Eerdmans, Grand Rapids, MI, pp. 470-74.

Simonsohn, U. I. (2011), A Common Justice: The Legal Allegiances of Christians and Jews under Early Islam, University of Pennsylvania Press, Philadelphia, PA.

Supiot, A. (2005), Homo Juridicus: Essai Sur La Fonction Anthropologique Du Droit, Seuil, Paris.

Tolan, J. (2002), Saracens: Islam in the Medieval European Imagination, Columbia University Press, New York, NY. 
Tolan, J.(2003), ““Cel Sarrazins Me Semblet Mult Herite”: L’hétérodoxie De L'autre Comme Justification De Conquête (Xième-Xiiième Siècles)', in L'expansion Occidentale: Xie Xve Siècles: Formes Et Conséquences, PUF, Paris, pp. 65-74.

Valkenberg, P. (2014), 'Una Religio in Rituum Varietate: Religious Pluralism, the Qur'an, and Nicholas of Cusa', in Nicolas of Cusa and Islam: Polemic and Dialogue in the Late Middle Ages, R. George-Tvrtkovic, D. F. Duclow I. C. Levy (eds). Brill, Leiden.

Voguet, E. (2013), 'Les Communautés Juives Du Maghreb Central À La Lumière Des FatwāS Malikites De La Fin Du Moyen Âge', in The Legal Status of Dimmī-S in the Islamic West (Second/Eighth-Ninth/Fifteenth Centuries), M. Fierro J. Tolan (eds), Brepols, Turnhoult, Pp. $295-306$.

Winroth, A. (2002), The Making of Gratian's Decretum, Cambridge University Press, Cambridge.

John TOLAN

John Tolan is professor of Medieval History at the University of Nantes (France) and author of numerous articles and books in medieval history and cultural studies, including Petrus Alfonsi and his Medieval Readers (1993) Saracens: Islam in the Medieval European Imagination (2002), Sons of Ishmael: Muslims through European Eyes in the Middle Ages (2008), Saint Francis and the Sultan: The Curious History of a ChristianMuslim Encounter (2009), and (with Gilles Veinstein and Henry Laurens) Europe and Islam (2012). He currently is director of a major project funded by the European Research Council, "RELMIN: The legal status of religious minorities in the EuroMediterranean world (5th-15th centuries)" (www.relmin.eu).

This publication is part of the research project RELMIN "“The Legal Status of Religious Minorities in the Euro-Mediterranean World $\left(5^{\text {th }}-15^{\text {th }}\right.$ centuries)"

The research leading to this publication has received funding from the European Research Council under the European Union's Seventh Framework Progamme (FP7/2007-2013)/ERC grant agreement $\mathrm{n}^{\circ} 249416$. 
${ }^{\mathrm{i}}$ For a good example of a cross-cultural history of a concept (in this case, 'purity'), see Discourses of Purity in Transcultural Perspective, Dynamics in the History of Religions (Leiden: Brill).

${ }^{\text {ii }}$ Cicero, Topica 7:31. Elsewhere, he gives a broader list of the sources of ius civile: 'ut si quis ius civile dicat id esse quod in legibus, senatus consultis, rebus iudicatis, iuris peritorum auctoritate, edictis magistratuum, more, aequitate consistat'. (Cicero, Topica 5:28) On these passages, see Mousourakis, G. (2007: 123-24) and Magdelain, A. (1978: 76-77).

iii For a discussion of the types of legal pluralism and their implications (particularly for the 21 st century), see Delmas-Marty. M. (2006)

iv These laws from the Theodosian Code and the canons of the cited Church councils may be found on the Relmin database: http://www.cn-telma.fr/relmin/index/. On the status of Jews in the early middle ages, see J. Tolan (ed.) (2013).

${ }^{\mathrm{v}}$ See Nemo-Pekelman, C. and Foschia, L. (2010), 'Introduction: Un aperçu des sources juridiques latines et grecques relatives aux juifs du $\mathrm{VI}^{\mathrm{e}}$ au $\mathrm{XI}^{\mathrm{e}}$ siècle', ibid.

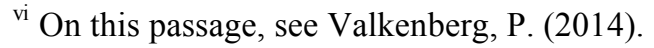

${ }^{\text {vii }}$ For a good introduction, see Schacht, J., 'Fikh', EI2 2:906-12.

viii The following section is based primarily on Fattal, A. (1995) and Arnaldez, A. et al. (1993: 263-89); see also Cahn, C., 'dhimma', EI2 2 :234-38.

${ }^{\text {ix }}$ Conditions for the Application of Islamic Law in Disputes between the Protected People, or between Christians and Muslims, ed. Emre Çelebi, http://www.cn-telma.fr/relmin/extrait252603/.

${ }^{x}$ Māwardī 'aī̄ B. Muhammad, Resolving Conflicts between Dhimmīs, Ahmed Oulddali (ed.), http://www.cntelma.fr/relmin/extrait136579/.

${ }^{x i}$ In Which Condition the Qadi May Intervene in Dhimmī Affairs? Ahmed Oulddali (ed.), http://www.cntelma.fr/relmin/extrait252252/.

${ }^{x i i}$ While dhimmi status is originally conceived for Jews and Christians, it is in some cases subsequently extended to other groups, such as Zoroastrians or Hindus; see Cahen, C., 'Dhimmi', EI ${ }^{2}$

xiii Kuttner, 'Revival of Jurisprudence', 310

${ }^{\text {xiv }}$ For a critical assessment of Angenendt's ideas, see the essays by M. Czock and H.-W. Goetz in Discourses of Purity in Transcultural Perspective.

${ }^{x v}$ Gratian, Decretum, E. Friedberg (ed.) (1879), B. Tauchnitz, Leipzig, repr. (1959) Akademische Druck- und Verlagsanstalt, Graz, D.1 d.a.c.1: 'Humanum genus duobus regitur, naturali uidelicet iure et moribus. Ius naturae est, quod in lege et euangelio continetur, quo quisque iubetur alii facere, quod sibi uult fieri, et prohibetur alii inferre, quod sibi nolit fieri. Unde Christus in euangelio: 'Omnia quecunque uultis ut faciant uobis homines, et uos eadem facite illis. Haec est enim lex et prophetae.'. [Matthew 7:12, cf. Luke 6:31] Omnes leges aut diuinae sunt, aut humanae. Diuinae natura, humanae moribus constant, ideoque he discrepant, quoniam aliae aliis gentibus placent. §. 1. Fas lex diuina est: ius lex humana. ... quod fas est, nomine diuinae uel naturalis legis accipiatur, nomine uero legis humanae mores iure conscripti et traditi intelligantur.' Text online at http://geschichte.digitale-sammlungen.de/decretum-gratiani/kapitel/dc_chapter_0_5, The three final senctences are taken from Isidore's Etymologies V:2.

${ }^{\text {xvi }}$ Notice no. 103877, Relmin project, 'The legal status of religious minorities in the Euro-Mediterranean world (5th-15th centuries)', Telma Web edition, IRHT, Institut de Recherche et d'Histoire des Textes, Orléans http://www.cn-telma.fr/relmin/extrait103877/ .

${ }^{\text {xvii }}$ For online editions of these texts, with commentary and translations, see Notice no. 1510 , Relmin project, 'The legal status of religious minorities in the Euro-Mediterranean world (5th-15th centuries)', Telma Web edition, IRHT, Institut de Recherche et d'Histoire des Textes, Orléans http://www.cntelma.fr/relmin/auteur1510/.

xviii On this ambivalence, in particular among Latin translators, copyists and readers of the Qur'an, see Burman, T. E. (2007). On Christian writers' portrayal of Islam as heresy, see Tolan, J. (2002).

xix http://www.cn-telma.fr/relmin/extrait1097/ 